\title{
TRAIT KEPRIBADIAN DAN KEPERCAYAAN KONSUMEN UNTUK BERBELANJA PADA TOKO ONLINE
}

\author{
Gumgum Gumelar \& Intan Pandina \\ e-mail: gumgumgumelarfr@gmail.com \\ Psikologi FIP Universitas Negeri Jakarta
}

\begin{abstract}
Abstrak: Penelitian ini dilakukan untuk mengetahui pengaruh antara trait kepribadian big five terhadap kepercayaan konsumen untuk berbelanja pada toko online. Penelitian ini dilakukan dengan melibatkan 120 subjek yang pernah melakukan pembelanjaan pada toko online yang berdomisili di DKI Jakarta. Pengambilan sampel menggunakan nonprobability incidental sampling. Instrumen penelitian ini terdiri atas 2 skala, yaitu skala kepercayaan konsumen dan skala trait kepribadian NEO-PI-R. Pengambilan data dilaksanakan pada Juli 2013. Hasil penelitian mengungkapkan, terdapat pengaruh yang signifikan antara trait kepribadian big five terhadap kepercayaan konsumen untuk berbelanja pada toko online. Persamaan regresi yaitu $\mathrm{Y}=38,315+0,044 \mathrm{X} 1+$ $0,076 \times 2+0,406 \times 3+0,269 \times 4+0,067 \times 5$ yang berarti, ada pengaruh positif antara trait kepribadian big five dengan kepercayaan konsumen untuk berbelanja dengan nilai $\mathrm{F}=4,618 ; \mathrm{p}=0,001<0.05$ (signifikan). Besarnya pengaruh trait kepribadian big five dengan kepercayaan konsumen adalah 0.132 yang artinya trait kepribadian big five mempengaruhi kepercayaan konsumen sebesar $13.2 \%$ dan sisanya 86.6\% dipengaruhi oleh faktor lain diluar trait kepribadian big five.
\end{abstract}

Kata-kata kunci: trait konsumen, trait kepribadian big fife, toko online.

\section{PERSONALITY TRAITS AND CONSUMER TRUST IN ONLINE SHOPPING BEHAVIOR}

\begin{abstract}
This study investigated the influence of the interaction between personality traits and consumer trust in online shopping behavior. The study included 120 subjects who ever did shopping in online shop and and lived in Jakarta. The research conducted at july 2013 employed quantitative approach with the regression analysis. The samples were selected using a nonprobability accidental sampling method. The instrument consisted of two scales: consumers trust and scale of big five personality traits. The result showed, there is significant effect between the big five personality traits toward consumers trust for shopping in online shop. Regression equation obtained: $Y=38,315+0,044 X 1+0,076$ X2 +0,406 $X 3+0,269 X 4+0,067 X 5$, which means there is a positive effect between the big five personality traits toward consumers trust for shopping in online shop with the value $F=4,618 ; p=0,001<0.05$ (significant). The amount of effect (Adjustment $R$ Square) to the occurrence of the big five personality traits and consumers trust for shopping in online shop is 0,132 meaning the big five personality traits affect the consumers trust for shopping in online shop by 13,2\% and the remaining $86,8 \%$ affected by another factors, outside of the big five personality traits.
\end{abstract}

Keywords: consumers trust, big five personality traits, online shop.

\section{PENDAHULUAN}

Saat ini perkembangan teknologi dan informasi semakinpesatdiIndonesia.Salahsatuperkembangannya ditandai dengan semakin meningkatnya penggunaan internet di masyarakat. Berdasarkan data yang diperoleh dari internetworldstats.com, pada tahun 2000 pengguna internet di Indonesia berjumlah 2.000.000 pengguna, kemudian meningkat pada tahun 2007 berjumlah 20.000 .000 pengguna dan terus meningkat hingga tahun 2012 peningkatannya mencapai 55.000.000 pengguna, data tersebut menunjukan jumlah masyarakat Indonesia yang menggunakan internet semakin meningkat setiap tahunnya dan diperkirakan pada tahun-tahun berikutnya pengguna internet di Indonesia akan terus meningkat.

Peningkatan penggunaan internet juga ditandai dengan semakin maraknya keberadaan warung internet serta fasilitas internet yang tersedia diberbagai tempat. Seperti menurut data dari AWARI (Asosiasi Warnet Indonesia), tercatat hingga akhir 2011 jumlah warnet di Indonesia mencapai 20.000 unit, sebagian besar tersebar di kota-kota kecil, jumlah ini meningkat kurang dari 10\% dibandingkan pada tahun 2010 (neraca.co.id). 
Pengunjung warung internet tersebut mulai dari anak kecil, remaja yang biasanya bermain game online atau mengerjakan tugas sekolah dan kuliahnya, hingga orang dewasa. Pada umumnya pengguna internet adalah individu yang menyisihkan waktunya untuk e-mail, melakukan browsing serta melakukan berbagai pencarian lain seperti halnya untuk kepentingan pendidikan dan bisnis (Sutedjo dalam Tunjungsari, 2010). Selain itu, banyaknya tempat-tempat umum seperti sekolah, kantor, tempat makan, pusat perbelanjaan, perpustakaan sudah menyediakan fasilitas hotspot wifi (wireless fidelity) yang semakin memudahkan masyarakat untuk mengakses internet. Cukup dengan membawa gadget mereka seperti smartphone, laptop, tablet dan yang lainnya, masyarakat bisa menggunakan fasilitas layanan internet secara gratis.

Keberadaan internet memudahkan masyarakat untuk berkomunikasi serta mendapatkan segala macam bentuk informasi yang mereka butuhkan. Kecanggihan internet saat ini dapat menunjang segala aktivitas yang dilakukan masyarakat di dalam kehidupannya sehari-hari. Peran internet di dalam kehidupan dapat digunakan sebagai sarana komunikasi yang praktis, dengan adanya internet masyarakat bisa berinteraksi dengan orang lain tanpa terhalang jarak dan waktu. Selain itu, internet difungsikan sebagai sumber pencarian berbagai macam informasi serta dapat berfungsi sebagai sarana bisnis yang digunakan untuk memenuhi kebutuhan masyarakat.

Setiap individu memiliki kebutuhan dan keinginan yang harus dipenuhi guna menyelaraskan kehidupannya. Timbulnya kebutuhan dan keinginan tersebut disebabkan oleh beberapa faktor seperti faktor sosial, ekonomi, psikologi, perkembangan fisik, religius, dan sebagainya (Swastha \& Handoko, 2000). Hal tersebut yang mendorong individu melakukan upaya untuk memenuhi kebutuhan serta keinginannya, salah satunya yakni dengan berbelanja. Belanja adalah kegiatan atau aktivitas yang berwujud dengan membeli barang atau jasa. Selain itu, belanja merupakan sebuah perilaku konsumen di mana konsumen mempunyai keinginan dalam membeli atau memilih suatu produk, berdasarkan pengalaman saat memilih, menggunakan, dan mengkonsumsi atau bahkan menginginkan suatu produk (Prasetyo \& Jannah, 2013). Belanja saat ini sudah merupakan hal yang telah menjadi gaya hidup serta kebiasaan yang dilakukan oleh setiap individu baik itu wanita maupun pria. Selanjutnya, pola perilaku berbelanja kebanyakan dibangkitkan oleh ketidakmampuan individu untuk mengendalikan dorongan-dorongan untuk membeli (Solomon dalam Astasari \& Sahrah, 2009). Dorongan keinginan berbelanja tersebut dapat dipenuhi dengan berbagai cara baik berbelanja secara konvensional maupun berbelanja secara online melalui internet.

Berbelanja secara konvensional sudah umum dikenal masyarakat, yaitu berbelanja dengan cara konsumen mendatangi secara langsung tempat perbelanjaan guna melihat, memilih dan membeli barang yang mereka butuhkan serta inginkan, dengan sistem pembayaran yang dilakukan saat itu juga ketika konsumen ingin mendapatkan barang. Di dalam prosesnya terjadi interaksi secara langsung antara penjual dan pembeli. Dengan berbelanja secara konvensional konsumen bisa memilih secara langsung barang yang mereka inginkan dengan mendatangi satu tempat ke tempat yang lainnya, berbelanja secara konvensional memiliki kelebihan seperti konsumen dapat melihat dan mengetahui kondisi dan kualitas barang secara langsung, interaksi secara langsung antara penjual dan pembeli memudahkan transaksi terkait harga dan pembayaran. Namun di sisi lain, dengan berbelanja secara konvensional tentunya konsumen perlu menyediakan waktu yang lebih untuk mendapatkan barang yang mereka inginkan.

Seiring dengan kemajuan teknologi dan informasi berbelanja dapat dilakukan melalui internet, yang mengiringi perubahan pola berbelanja masyarakat menjadi lebih praktis dengan melakukannya secara online. Perilaku membeli secara online adalah proses membeli produk atau jasa melalui media internet (Liang dan Lai, 2000).

Kekhasan dari proses membeli secara online adalah ketika konsumen menggunakan internet dan mencari-cari informasi yang berkaitan dengan barang yang mereka butuhkan. Secara lebih detail, perilaku membeli secara online adalah tindakan konsumen dari mulai mengunjungi toko online, membuat pesanan untuk membeli produk, serta menyetujui kontrak untuk menerima dan menggunakan pelayanan secara online (Liang \& Lai, 2000). Belanja online merupakan proses pembelian barang yang dilakukan dengan menggunakan fasilitas internet yang dapat dilakukan di mana saja serta kapan saja sesuai kebutuhan dan keinginan konsumen. Di dalam prosesnya, konsumen dan penjual tidak berinteraksi secara langsung dengan bertatap muka melainkan melalui media online yang disediakan seperti melalui web toko online yang saat ini sangat dikenal di masyarakat seperti tokobagus. com, berniaga.com, kaskus.co.id dan lain-lain, selain itu bisa didapatkan melalui blog-blog toko online, facebook, twitter, blackberry messenger, instragram serta 
fasilitas secara online lainnya yang saat ini sedang marak penggunaannya, sistem pembayarannya cukup dengan konsumen mentransfer uang kepada penjual, kemudian penjual mengirimkan barang yang dibeli kepada konsumen.

Semakin maraknya penjual melalui toko online merupakan hal pendukung bagi para konsumen untuk membeli barang yang mereka butuhkan serta inginkan secara online. Pertimbangan para konsumen memilih untuk berbelanja di toko online didasari oleh kemudahan yang didapatkannya. Barang yang ditawarkan pun semakin beragam, mulai dari gadget, barang elektronik, buku, pakaian beserta aksesorisnya hingga berbagai macam kebutuhan mendasar seperti makanan-makanan dan minuman yang unik yang terkadang sulit ditemui jika berbelanja secara konvensional. Dengan menggunakan fasilitas berbelanja melalui toko online, konsumen bisa dengan mudah mendapatkan barang yang diinginkannya tanpa harus terhalang jarak, konsumen dapat membeli barang yang berasal dari luar kota atau luar negeri tanpa harus mendatangi tempat penjualannya tersebut, hal tersebut menjadikan berbelanja secara online dinilai lebih praktis dibandingkan dengan berbelanja secara konvensional.

Kemudahan lain yang didapatkan dengan berbelanja di toko online adalah hematnya waktu dan biaya yang digunakan. Berbelanja secara online memberikan kenyamanan, pelanggan tidak perlu bergelut dengan lalu lintas, tidak perlu mencari tempat parkir dan berjalan dari toko ke toko (Kotler dan Armstrong (2001). Dengan demikian, konsumen dapat hemat biaya dan waktu yang digunakan untuk pergi mencari barang yang mereka butuhkan serta inginkan. Barang yang ditawarkan di toko online pun beragam dan tidak tertinggal dari model-model yang berada dipasaran, bahkan barang-barang yang dijual di toko online terkadang memiliki model yang lebih terbaru dibandingkan dipasaran, sehingga konsumen pun semakin tertarik untuk berbelanja. Untuk berbelanja di toko online konsumen hanya perlu menggunakan gadget mereka untuk mengakses layanan internet kemudian mereka akan mendapatkan sajian barangbarang yang dijual oleh berbagai penjual dan mereka bisa memilih sesuka hati barang yang ingin mereka beli dengan mudah, cepat, selain itu dengan berbelanja di toko online konsumen dapat melakukannya di mana dan kapan saja konsumen membutuhkan serta menginginkannya.

Di sisi lain, perkembangan dan maraknya toko online yang hadir di Indonesia belum dapat sepenuhnya menarik minat seluruh masyarakat untuk berbelanja secara online. Masih banyak masyarakat yang enggan untuk selalu berbelanja pada toko online. Banyak alasan yang melatarbelakangi masyarakat tidak tertarik untuk melakukan pembelian secara online, diantaranya adalah faktor kepercayaan dan keamanan (Nazar \& Syahran, 2008). Sistem keamanan di dalam prosesnya, resiko penipuan didalam sistem transaksinya karena data pemilik toko online yang kurang jelas biasanya sering terjadi dan mempengaruhi tingkat kepercayaan konsumen terhadap toko online.

Menurut hasil riset pada tahun 2001 yang dilakukan oleh clearcommerce.com yang berkantor di Texas, Indonesia dinyatakan berada pada urutan kedua negara asal pelaku cyberfraud setelah Ukraina. Hasilnya menunjukkan bahwa sekitar 20\% dari total transaksi kartu kredit Indonesia di internet adalah fraud. Riset tersebut mensurvei 1.137 e-vendors, 6 juta transaksi, dan 40 ribu pelanggan (Utoyo, 2003 dalam Pratama, 2012).

Salah satu contoh kasus penipuan didalam berbelanja online dialami oleh Aprilia Paramitasari. Aprilia tertipu oleh toko online yang bernama Aulia Celluler Shop. Kejadian terjadi pada 14 Januari 2011, Aprilia berniat membeli tiga buah laptop merek Sony Vaio VPCEB16FG 14 inch baru yang dijual Rp. 3.750.000/unit. Aprilia menganggap harga tersebut sangatlah murah untuk kelas Sony Vaio yang dipasaran harganya masih mencapai kisaran Rp. 8.000.000-Rp.9.000.000/ unit, dengan murahnya harga yang ditawarkan toko online tersebut maka Aprilia pun tertarik untuk membelinya dengan mengajak kakak serta temannya untuk membeli laptop tersebut. Transaksi dilakukan dan Aprilia mengirimkan uang kepada pemilik toko online tersebut sebesar Rp. 11.600.000 dengan harapan bisa mendapatkan tiga unit laptopnya, namun setelah pembayaran dilakukan Aprilia tidak kunjung mendapatkan barang yang dipesannya dan pemilik toko online tempat Aprilia membeli pun tidak dapat dihubungi kembali (kompasiana.com).

Berdasarkan adanya kasus penipuan tentu sangat berdampak pada kepercayaan konsumen terhadap toko online. Adanya kasus penipuan memunculkan rasa ketidakpercayaan konsumen untuk kembali berbelanja secara online. Faktor lain yang menjadi alasan konsumen belum sepenuhnya percaya untuk berbelanja pada toko online adalah keadaan barang asli yang dibeli oleh konsumen seringkali tidak sesuai seperti yang ditampilkan pada gambar yang terdapat pada situs toko online tersebut, hal tersebut tentu memberikan dampak kekecewaan pada konsumen saat menerima barang 
yang mereka beli, sehingga konsumen enggan untuk berbelanja secara online kembali. Adanya kelebihan serta kekurangan yang diberikan oleh toko online berpengaruh pada keinginan konsumen dalam berbelanja, keinginan tersebut didasari oleh rasa percaya dan ketidakpercayaan konsumen pada toko online.

Kepercayaan konsumen terhadap toko online sangat berpengaruh terhadap perilaku berbelanja secara online. Kepercayaan merupakan keyakinan konsumen terhadap niat baik, integritas dan kompetensi penjual dalam suatu situasi, kesediaan konsumen untuk menerima resiko apapun, serta kesediaan konsumen untuk memberikan informasi mengenai dirinya ketika melakukan transaksi melalui media internet (McKnight dalam Bonanni \& Cyr, 2004). Kepercayaan konsumen terhadap toko online menciptakan keselarasan didalam proses jual beli tersebut, dengan adanya rasa percaya pada toko online maka intensitas keinginan berbelanja pada toko online pun semakin meningkat dan begitu pun sebaliknya. Ketika konsumen tidak memiliki rasa kepercayaan kepada toko online, maka berdampak pada rendahnya keinginan konsumen untuk berbelanja secara online. Kepercayaan konsumen pada umumnya diperkuat berdasarkan pengalaman, seorang konsumen yang pernah melakukan pembelanjaan pada toko online dan bisa mendapatkan barang dan jasa sesuai dengan apa yang mereka inginkan akan berdampak positif pada kepercayaan konsumen terhadap toko online. Selain itu pengalaman dari orang lain juga berfungsi sebagai informasi penguat kepercayaan didalam diri konsumen untuk bersedia mencoba berbelanja pada toko online. Toko online yang menyertakan identitas secara jelas tentang pemiliknya juga dapat mempengaruhi kepercayaan konsumen terhadap toko online, dengan adanya identitas yang jelas konsumen akan lebih percaya kepada toko online tersebut.

Keputusan konsumen untuk bersedia berbelanja di toko online dipengaruhi oleh kepercayaan yang dimiliki oleh masing-masing individu. Faktor kepribadian pada masing-masing individu turut serta dalam mempengaruhi perbedaan kepercayaan untuk berbelanja pada toko online tersebut. Seperti yang dijelaskan oleh Ghufron dan Risnawita (2010) terkait kepribadian, bahwa masing-masing individu berbeda caranya dalam berperasaan, mengembangkan pikiranpikirannya dan menentukan minat pribadinya, hal ini berhubungan dengan kenyataan bahwa setiap orang berbeda dalam mengolah dan bereaksi terhadap berbagai kebutuhan yang berasal dari luar dirinya. Kepribadian merupakan aspek psikologi yang penting dalam menentukan perilaku individu. Kepribadian ini juga ikut mewarnai perbedaan yang pada setiap manusia. Perbedaan yang berasal dari masing-masing kepribadian individu menghasilkan persepsi yang berbeda pada setiap individu dalam menyikapi segala hal termasuk kepercayaan.

Kepribadian merupakan suatu organisasi dinamis dalam diri seseorang yang merupakan sistem psikofisis yang menghasilkan pola-pola karakteristik seseorang dalam perilaku, pikiran dan perasaan (Carver \& Scheier, 1996), sedangkan Suryabrata (1988) menjelaskan bahwa kepribadian merupakan suatu kebulatan dari aspek-aspek jasmaniah dan ruhaniah yang bersifat dinamis dalam hubungannya dengan lingkungan (Ghufron \& Risnawita, 2010). Fieldman (1994) menjelaskan terdapat beberapa pendekatan yang dikemukakan oleh para ahli untuk memahami kepribadian. Salah satu pendekatan yang digunakan adalah teori trait. Teori trait merupakan sebuah model untuk mengidentifikasi trait-trait dasar yang diperlukan untuk menggambarkan suatu kepribadian. Trait didefinisikan sebagai suatu dimensi yang menetap dari karakteristik kepribadian, hal tersebut membedakan individu dengan individu lain. Terdapat teori yang mengemukakan adanya lima dimensi kepribadian yang dikembangkan oleh McCrae dan Costa, yang dikenal dengan Big five Personality Traits. Kelima dimensi tersebut adalah Neuroticism, Extraversion, Agreeableness, Openness to Experience dan Conscientiousness. Berdasarkan penjabaran tersebut, maka penulis melakukan penelitian yang berjudul "Pengaruh Trait Kepribadian Big five terhadap Kepercayaan Konsumen untuk Berbelanja pada Toko Online".

\section{METODE PENELITIAN}

Penelitian ini bertujuan untuk mengetahui pengaruh trait kepribadian big five terhadap kepercayaan konsumen untuk berbelanja pada toko online. Metode yang digunakan didalam penelitian ini adalah metode penelitian kuantitatif dengan teknik pengambilan sampel menggunakan metode nonprobability sampling yaitu accidental sampling . Pelaksanaan penelitian ini dimulai sejak awal tahun 2013 dan pengambilan data diambil di bulan Juli 2013, tempat pelaksanaan penelitian di kota Jakarta.

Sampel didalam penelitian ini berjumlah 120 responden dengan kriteria sampel yakni: individu yang berusia 18 sampai 40 tahun, pernah melakukan transaksi pembelanjaan pada toko online serta berdomisili di wilayah DKI Jakarta. Teknik 
pengumpulan data menggunakan metode kuesioner dengan skala pengukuran Likert.

Terdapat dua variabel didalam penelitian ini yaitu variabel bebas $(X)$ trait kepribadian big five dan variabel tergantung $(\mathrm{Y})$ kepercayaan konsumen. Data dalam penelitian ini dikumpulkan dengan menggunakan dua buah skala pengukuran, yaitu skala yang mengukur kepercayaan konsumen berdasarkan acuan teori kepercayaan konsumen oleh Mcknight, Choudury dan Kacmar (2002) dan skala yang mengukur trait kepribadian big five yang merupakan instrumen adaptasi yang berasal dari organisasi International Personality Item Pool (IPIP) yakni NEO-PI-R.

Untuk nilai koefisien reliabilitas skala kepercayaan konsumen sebesar 0.826 dan untuk skala kepribadian sebesar 0.782 (kedua skala tersebut masuk ke dalam kreteria reliable). Dalam proses pengolahan data yang digunakan untuk menguji hipotesa digunakan analisis regresi linear menggunakan software SPSS Ver. 11.

\section{HASIL DAN PEMBAHASAN}

Penelitian ini bertujuan untuk mengetahui apakah terdapat pengaruh yang signifikan antara trait kepribadian big five terhadap kepercayaan konsumen untuk berbelanja pada toko online. Berdasarkan hasil perhitungan statistik analisis regresi maka diperoleh hasil dalam tabel 1.

Tabel 1. Hasil Perhitungan Analisis Regresi

\begin{tabular}{lcl}
\hline & F & Sig. \\
\hline Regression & 4,618 & .001 \\
\hline
\end{tabular}

Berdasarkan hasil analisis regresi menunjukkan nilai $F$ regresi yang diperoleh sebesar 4,618 dengan nilai signifikansi $p=0,001(p<0,05)$. Dengan demikian artinya secara keseluruhan trait kepribadian big five memiliki pengaruh terhadap kepercayaan konsumen untuk berbelanja pada toko online.

Kepribadian merupakan aspek psikologi yang penting dalam menentukan perilaku individu, seperti yang dijelaskan oleh Ghufron dan Risnawita (2010) terkait kepribadian, bahwa masing-masing individu berbeda caranya dalam berperasaan, mengembangkan pikiran-pikirannya dan menentukan minat pribadinya, hal ini berhubungan dengan kenyataan bahwa setiap orang berbeda dalam mengolah dan bereaksi terhadap berbagai kebutuhan yang berasal dari luar dirinya. Carver dan Scheier (1996, dalam Ghufron dan Risnawita (2010) menjelaskan kepribadian merupakan suatu organisasi dinamis dalam diri seseorang yang merupakan sistem psikofisis yang menghasilkan pola-pola karakteristik seseorang dalam perilaku, pikiran dan perasaan. Fieldman (1994) menjelaskan ada beberapa pendekatan yang dikemukakan oleh para ahli untuk memahami kepribadian. Salah satu pendekatan yang digunakan adalah teori trait. Teori trait merupakan sebuah model untuk mengidentifikasi trait-trait dasar yang diperlukan untuk menggambarkan suatu kepribadian. Trait didefinisikan sebagai suatu dimensi yang menetap dari karakteristik kepribadian, hal tersebut membedakan individu dengan individu lain. Trait kepribadian individu membentuk perilaku, pikiran dan perasaan yang berbeda-beda pada setiap individu dan hal tersebut yang mempengaruhi persepsi individu tentang segala hal termasuk kepercayaan untuk berbelanja pada toko online.

Tabel 2. Persamaan Regresi

\begin{tabular}{lcc} 
& Ceeficients & Sis \\
\hline (Ceastant) & 38,315 & 0,000 \\
Nearedichan & 0,044 & 0,864 \\
Extrancrsios & 0,076 & 0,634 \\
Openness To & 0,406 & 0,043 \\
Experience & 0,269 & 0,008 \\
Agrceableness & 0,067 & 0,705 \\
Conscientiossaess &
\end{tabular}

Konstanta variabel kepercayaan konsumen sebesar 38,315 sedangkan koefisien regresi variabel trait kepribadian big five pada masing-masing dimensi sebesar 0,044 pada neuroticism, 0,076 pada extraversion, 0,406 pada openness to experience, 0,269 pada agreeableness dan 0,067 pada conscientiousness. Berdasarkan data yang tersedia, maka dapat disusun persamaan regresi sebagai berikut:

$\mathrm{Y}=\mathbf{3 8 , 3 1 5 + 0 , 0 4 4} \mathbf{X 1}+\mathbf{0 , 0 7 6}$
Keterangan:
$\mathrm{Y}=$ Kepercayaan konsumen
$\mathrm{X} 1=$ Neuroticism
$\mathrm{X} 2$ = Extraversion
$\mathrm{X} 3$ = Openness to experience
$\mathrm{X} 4=$ Agreeableness
$\mathrm{X} 5$ = Conscientiousness

Berdasarkan persamaan regresi diatas dapat dianalisis bahwa dari kelima dimensi trait kepribadian big five, terdapat satu dimensi yang memiliki nilai signifikansi $<0,05$ yaitu openness to experience. Nilai koefisien regresi openness to experience sebesar 0,406 dengan signifikansi sebesar 0,043 yang artinya dimensi openness to experience berpengaruh signifikan dan positif terhadap kepercayaan konsumen. Hal ini menunjukkan semakin tinggi dimensi openness to experience pada diri konsumen maka semakin tinggi juga kepercayaan untuk berbelanja pada toko online. Sementara untuk keempat dimensi lainnya yaitu neu- 
roticism, extraversion, agreeableness dan conscientiousness memiliki nilai signifikansi > 0,05, maka keempat dimensi tersebut tidak signifikan.

Dimensi openness to experience menurut McCrae dan Costa (1992, dalam Pervin, Cervone \& John, 2010) menggambarkan individu yang cenderung tinggi dalam dimensi ini memiliki rasa ingin tahu yang tinggi, memiliki minat yang luas serta tidak tradisional. Rasa ingin tahu yang tinggi menjadi faktor pendukung kepercayaan konsumen memilih untuk berbelanja pada toko online, dengan adanya keinginan tersebut individu bersedia mencoba untuk berbelanja pada toko online dan tidak terhalang oleh segala resikoresiko yang bisa terjadi. Individu yang memiliki minat yang luas akan mencoba segala hal yang diinginkan olehnya, termasuk keinginan berbelanja pada toko online. Kecenderungan tidak bersifat tradisional menggambarkan bahwa individu dengan dimensi openness to experience terbuka pada pengalaman dan teknologi, sehingga memiliki keinginan untuk berbelanja melalui sistem online.

Tabel 3. Hasil Perhitungan Regresi

\begin{tabular}{cccc}
\hline$R$ & $\begin{array}{c}\text { R } \\
\text { Square }\end{array}$ & $\begin{array}{c}\text { Adjusted } \\
\text { R Square }\end{array}$ & $\begin{array}{c}\text { Std. Error of } \\
\text { the Estimate }\end{array}$ \\
\hline 0.410 & 0,168 & 0,132 & 7,120 \\
\hline
\end{tabular}

Besarnya kontribusi dari trait kepribadian big five terhadap kepercayaan konsumen untuk berbelanja pada toko online dapat diketahui dengan melihat hasil Adjusted R Square. Berdasarkan tabel tersebut diperoleh nilai Adjusted R Square sebesar 0,132 yang artinya trait kepribadian big five yang terdiri dari neuroticism, extraversion, openness to experience, agreeableness dan conscientiousness mempengaruhi kepercayaan konsumen sebesar 13,2\% dan sisanya $86,8 \%$ dipengaruhi oleh faktor selain trait kepribadian big five.

Faktor-faktor lain yang diasumsikan mempengaruhi kepercayaan konsumen seperti yang dikemukakan oleh Morgan dan Hunt (1994) antara lain, shared value yakni perilaku, tujuan serta peraturan yang telah disepakati oleh kedua belah pihak, kesepakatan tersebut diperlukan untuk meningkatkan kepercayaan dalam suatu hubungan terutama didalam transaksi online. Kesepakatan yang terjalin antara kedua belah pihak dimana pada transaksi online terjadi antara konsumen dan produsen dapat berpengaruh positif dalam membentuk kepercayaan konsumen. Adanya kesepakatan yang telah terjalin akan membuat konsumen lebih percaya dan bersedia melakukan transaksi online karena jika tidak ada kesepakatan konsumen akan memiliki keraguan untuk bertransaksi secara online. Selain itu komunikasi yang baik antara kedua belah pihak yang menjalin suatu hubungan atau komitmen merupakan hal yang mempengaruhi kepercayaan individu (Morgan \& Hunt, 1994), semakin efektif komunikasi yang terjalin maka semakin meningkatkan kepercayaan individu pada pihak lain. Dalam transaksi online komunikasi merupakan hal utama yang mendukung kepercayaan, tanpa adanya komunikasi yang efektif akan sulit menciptakan rasa kepercayaan konsumen. Perilaku opportunistik juga merupakan salah satu faktor yang mempengaruhi kepercayaan (Morgan \& Hunt, 1994). Perilaku produsen mengambil keuntungan sendiri dari konsumen berpengaruh pada kurang percayanya konsumen pada transaksi yang dijalani. Ketika konsumen sudah memiliki persepsi yang negatif terhadap produsen khususnya didalam transaksi online maka tingkat kepercayaan konsumen untuk melakukan transaksi pun akan rendah.

\section{PENUTUP}

\section{Kesimpulan}

Penelitian ini mengkaji pengaruh antara trait kepribadian big five terhadap kepercayaan konsumen untuk berbelanja pada toko online. Berdasarkan uji coba penelitian didapatkan hasil bahwa terdapat pengaruh yang signifikan antara trait kepribadian big five terhadap kepercayaan konsumen untuk berbelanja pada toko online. Besarnya kontribusi dari trait kepribadian big five terhadap kepercayaan konsumen untuk berbelanja pada toko online sebesar 13,2 \% dan sisanya $86,8 \%$ dipengaruhi oleh faktor selain trait kepribadian big five.

Semakin berkembangnya toko online memudahkan konsumen untuk mendapatkan barang yang diinginkan, kefektifitasan waktu dan praktisnya berbelanja. Dalam usaha untuk memasarkan produk online, maka produsen harus dengan seksama memahami keragaman sifat dan kepribadian konsumen guna mencari target pemasaran yang sesuai. Serta diharpakan produsen dapat terus meningkatkan kualitas guna meningkatkan kepercayaan konsumen di dalam transaksi online.

Dengan penelitian ini diharapkan dapat memberikan gambaran untuk produsen dalam memaksimalkan kinerjanya untuk mencari mangsa pasar toko online yang dijalankan serta dapat meningkatkan pemasaran dengan berusaha menciptakan rasa kepercayaan pada konsumen. Kepercayaan merupakan faktor yang penting 
dalam transaksi online, terdapat banyak faktor yang mempengaruhi tingkat kepercayaan konsumen seperti shared value, komunikasi, hendaknya para produsen meningkatkan efektifitas hal tersebut dan menghindari perilaku oportunistik demi menjaga kepercayaan konsumen. Hasil penelitian in juga dapat diterapkan pada bidang psikologi konsumen, dimana produsen yang bergerak pada usaha toko online harus berusaha menjalin hubungan efektif yang dapat meningkatkan kepercayaan pada konsumen.

\section{Saran}

Untuk penelitian selanjutnya perlu dicermati penggunaan skala pengukuran kepercayaan dan skala kepribadian yang terstandarisasi dan memiliki validitas tinggi agar item yang tersedia dapat mengukur setiap dimensi dengan lebih akurat. Teknik pengambilan data sebaiknya dilakukan dengan menggunakan metode randomized sampling dengan jumlah responden lebih banyak dan wilayah penelitian lebih luas sehingga hasil dari temuan lebih dapat digeneralisasikan terhadap populasi dengan baik agar dapat menyeimbangkan proporsi subjek yang mewakili setiap dimensi kepribadian big five.

Penelitian tentang kepribadian big-five dan pembelanjaan pada toko online masih dalam tahap pengembangan penelitian secara komprehensif. Sehingga penelitian tentang pembelanjaan pada toko online masih memiliki kesempatan dan peluang untuk menggali aspek-aspek individu lain diluar kepribadian. Sebagai variable yang dapat mempengaruhi pengambilan keputusan individu untuk berbelanja pada toko online.

\section{DAFTAR PUSTAKA}

Astasari, A. R., \& Sahrah, A. (2009). hubungan antara konformitas dengan perilaku membeli impulsifpada remaja putri. Universitas Wangsa Manggala, Yogyakarta.

Bonanni, C., \& Cyr, D. (2004). Trust and loyalty: A cross cultural comparison. Simon Fraser University. Canada.

Fieldman, R. S. (1994). Essential of understanding psychology. New York: Mc Graw Hill.

Ghufron, M. N., \& Risnawita, S. R. (2010). Teori-teori psikologi. Yogyakarta: Ar-Rizz. http:/ / lifestyle.kompasiana.com / u r ban/2011/01/17/penipuan-online-shop-sebuah-testimoni-333811.html

http://www.internetworldstats.com/asia/id.htm

http://www.neraca.co.id/harian/article/15004/ Pasar.Warnet.Masih.Terbuka.Lebar

ipip.ori.org. (1992). International personality item pool organization. Retrieved from IPIP Organization. Web site: http:/ /ipip.ori.org/newNEODomainsKey.htm

Kotler, P., \& Armstrong, G. (2001). Prinsip-prinsip pemasaran jilid 1 (8th ed). Jakarta: Erlangga.

Liang, T. P., \& Lai, H. J. (2000). Electronic store design and consumer choice: An empirical study. 33rd Hawaii International Conference on System Sciences.

McKnight, D. H., Choudhury, V., \& Kacmar, C. (2002). Developing and validating trust measures for e-commerce: an integrative typology. Information systems research, 13(3), 334-359.

Morgan, R. M., \& Hunt, S. D. (1994). The commitment trust theory of relationship marketing. The journal of marketing, 20-38.

Nazar, M. R., \& Syahran (2008). Pengaruh privasi, kemanan, kepercayaan dan pengalaman terhadap niat untuk bertransaksi secara online. Tesis. Fakultas Ekonomi Universitas Gajah Mada, Yogyakarta.

Pervin, L. A., D. Cervone, \& O. P. John. (2010). Psikologi kepribadian teori dan penelitian (9th ed). (A. K. Anwar, Penerjemah). Jakarta: Kencana.

Prasetyo, M. D., \& Jannah, M. (2013). Perbedaan tingkat online shopping ditinjau dari orientasi lokus kontrol pada mahasiswi fakultas psikologi Universitas Surabaya (ubaya). Character, Volume 01, Nomor 02, Tahun 2013. Fakultas Ilmu Pendidikan Universitas Negeri Surabaya.

Pratama, Y. N. (2012). Pengaruh privasi dan kepercayaan terhadap internet pada perilaku pembelian online (tesis). Fakultas Ekonomika dan Bisnis Universitas Gajah Mada, Yogyakarta, h.3.

Swastha, B., \& Handoko, T. H. (2000). Manajemen pemasaran. Yogyakarta: BPFE UGM.

Tunjungsari, G. (2010). Correlation between perception of fashion product quality and purchasing intention via website on the students of psychology faculty diponegoro university. Fakultas Psikologi Universitas Diponegoro, Semarang. 